\title{
Potential Biological Control Agents for Soilborne Fungal Pathogens in Tennessee Snap Bean Farms
}

\author{
Jacqueline Joshua and Margaret T. Mmbaga \\ Tennessee State University, College of Agriculture, Department of Agricultural \\ and Environmental Sciences, Nashville, TN 37209
}

Additional index words. disease management, dual culture technique, Fusarium species, Macrophomina root rot, rhizosphere, root rot pathogens

\begin{abstract}
Fungi isolated from snap bean roots and rhizosphere soil where fungicides are not used included Fusarium oxysporum, Fusarium equiseti, Fusarium subglutinans, Fusarium camptoceras, Fusarium chlamydosporum, Fusarium verticillioides, Fusarium proliferatum, Fusarium acuminatum, Fusarium solani, Peyronellaea pinodella, Macrophomina phaseolina, and Glomerella guttata. Only $P$. pinodella, M. phaseolina, and $F$. oxysporum were isolated on symptomatic plants. These soilborne fungi are common pathogens of diverse host plants. Pathogenicity tests under controlled environment demonstrated that these fungi were pathogenic on snap beans. Subsequently, bacterial endophytes isolated from snap bean roots, papaya roots and stems, and dogwood stems were evaluated as potential biological control agents against these diverse fungi. All bacteria isolated, including Bacillus vallismortis (PS), Bacillus amyloliquefaciens (Psl), Bacillus subtilis (Prt), Bacillus thuringiensis (Y and IMC8), Enterobacter sp. (E), Stenotrophomonas sp. (B17A), and Serratia sp. (B17B) suppressed growth of the fungal pathogens in vitro and formed clear inhibition zones in petri dish dual cultures. Growth media taken from the inhibition zones suppressed growth of the fungal pathogens in the absence of the bacterial cells, suggesting that the bacteria released unidentified antagonistic biochemical substances into the media. This study constitutes an initial screening of endophytes as biological control agents against diverse fungal pathogens and forms a basis for the discovery of novel strains that can be further developed and integrated into disease management systems for diverse fungal pathogens. Isolates B. vallismortis (PS), B. amyloliquefaciens (Psl), B. subtilis (Prt), and B. thuringiensis (Y IMC8) exhibited the best performance as potential biological control agents paving the way for larger-scale in vivo studies and characterization of their interactions with fungal pathogens.
\end{abstract}

Fungal pathogens impose major constraints on agricultural production globally (Collinge et al., 2010). Disease management strategies have relied heavily on conventional chemical fungicides. Persistent challenges associated with the use of conventional fungicides include toxicity to humans and nontarget organisms, environmental pollution, and development of fungicide resistance (Barnard, 2010; Burns et al., 2013; Kelley et al., 2013; Norgaard and Cedergreen, 2010). Attempts to introduce eco-friendly microbial pesticides as biological agents for combating fungal pathogens have been hampered by the lack of

Received for publication 29 Mar. 2019. Accepted for publication 29 July 2019.

Published online 20 May 2020.

We thank Drs. Richard Hall and Roger Sauvé for their valuable contribution in manuscript reviews. This project was funded by USDA/NIFA Award No. 2010-38821-21477.

Current address for J.J.: Bayer, Crop Sciences, Chesterfield, MO 63017.

M.T.M is the corresponding author. E-mail: mmmbaga@tnstate.edu.

This is an open access article distributed under the CC BY-NC-ND license (https://creativecommons. org/licenses/by-nc-nd/4.0/). major soilborne pathogens such as Pythium damping-off, wilt, and pod rot (various Pythium species), Rhizoctonia, Fusarium (F. solani f. sp. phaseoli and $F$. oxysporum $f$. sp. phaseoli), Phytophthora spp., Sclerotium rolfsii, and Macrophomina phaseolina (Bost et al., 2013). Seed treatments with chemical fungicides have been useful in managing soilborne pathogens because these treatments protect plants during the seedling stage when they are most vulnerable and can eliminate the need for foliar fungicide applications later in the season. Although the practice is almost always effective, the chemical fungicides kill nontarget organisms that may provide natural protection to plants against pathogens. In addition, their nontarget environmental impacts include toxicity hazards to humans and animals consuming treated plants. The development of pathogen resistance to chemicals is an additional problem that has led to the search for alternative methods (Pertot et al., 2015). Furthermore, most soilborne fungal pathogens form resting structures, such as sclerotia, oospores, and chlamydospores, which have the ability to survive in the soil for many years and are very difficult to control (Bost, 2006; Bost et al., 2013). Biological control agents (BCAs) can be helpful in decreasing the soil inoculum potential of soilborne pathogens and therefore improve soil health and overall health of plants (Pertot et al., 2015).

Root rot diseases accounted for estimated losses of $30 \%$ in snap beans in Tennessee in 2002 (Bost et al., 2013). Most root rot damage occurs when plants are young and damage may remain minimal when plants are growing vigorously and conditions for disease problems are unfavorable. However, when environmental conditions favoring the pathogen persist through flowering, yield losses can approach $100 \%$. Cultural practices have been useful in combating root rot diseases, and constitute the main method used in organic production systems. However, the practice does not provide adequate protection, resulting in high yield losses and high prices of organic produce. With increasing consumer awareness of toxicity hazards posed by fungicides, there is a growing demand for organic produce, and new products suited to organic production systems are needed not only to reduce losses and boost production, but also to reduce sale prices, especially in fruits and vegetables. The use of beneficial microorganisms as part of integrated disease management systems can complement cultural practices and improve disease management (Mmbaga et al., 2018a; Pal and Gardener, 2011).

Our previous studies identified beneficial bacteria that significantly suppressed powdery mildew disease severity in flowering dogwood (Mmbaga and Sauvé, 2009; Mmbaga et al., 2008 , 2016). Some BCAs applied on the roots suppressed powdery mildew on dogwood foliage (Mmbaga et al., 2016), and were effective against Macrophomina root rot disease (Mmbaga et al., 2018b). The objectives of this study were 1) to identify soilborne pathogens from snap bean roots and rhizosphere soil where fungicides are not used in organically produced snap beans, and 2) to screen endophytic bacteria for bioactivity in 
suppressing growth of diverse soilborne fungal pathogens and identify novel strains that can be further developed as BCAs.

\section{Materials and Methods}

Isolation and identification of root rot pathogens and endophytic BCAs. Isolation of root rot pathogens in snap beans (Phaseolus vulgaris) was conducted at four different locations, including Tennessee State University (TSU) bean research fields, TSU outreach community gardens growing diverse horticultural crops including snap beans and other vegetables, and selected organic vegetable farms in Palmyra and Indian Mount, TN. Each farm was inspected for symptomatic plants that displayed growth stunting, wilting, or leaf yellowing/browning or necrotic lesions on the collar regions. Ten sample plants with different symptoms were collected and taken back to the laboratory for pathogen isolation. Soil from around the roots (rhizosphere soil) was also collected for the isolation of soilborne pathogens. Direct isolation of potential pathogens from the symptomatic plants was done by using small pieces of tissue in the root and collar regions. The small plant tissues were cleaned and surface disinfected by dipping in $10 \% \mathrm{NaOCl}$ for $2 \mathrm{~min}$ and then rinsed twice in sterile water, blotted dry using heatsterilized paper towels, and plated on acidified potato dextrose agar media (APDA) containing $0.1 \%$ lactic acid. Bacteria growing as endophytes inside healthy and asymptomatic plants were isolated from roots of beans, stems and leaves of papaya (Carica papaya), and stem of dogwood, Cornus florida. Small pieces of the plant tissues were disinfected by dipping in $10 \% \mathrm{NaOCl}$ and plated on nutrient agar media (NA), as described previously.

Isolation of soilborne pathogens from rhizosphere soil was done by using a baiting technique in which rhizosphere soil was placed in large petri dishes and moistened with sterilized water, two plates for each sample. Based on our previous results in which surface-disinfected carrots, apple, pine needles, and leaves of Pieris japonica were most effective in the isolation of diverse soilborne pathogens from rhizosphere soil, these baits were selected and placed in the soil for $48 \mathrm{~h}$ and then aseptically removed, blotted dry using heat-sterilized tissue paper, and plated on APDA. Pure cultures were obtained by subculturing.

Pathogenicity tests on snap beans. A total of 27 fungal isolates that exhibited different morphological features were identified (Table 1). Of these, 16 isolates were from plant tissue and 11 isolates were from rhizosphere soil. The isolates were tested for pathogenicity on snap bean seedlings grown in clear plastic containers lined with moist paper towels and maintained in a growth chamber at 24 to $26{ }^{\circ} \mathrm{C}$ and 12-h fluorescent light. Plant inoculation with test isolates was done $7 \mathrm{~d}$ after sowing using 5-mm mycelial disks placed on the plant roots, one disk per plant with the mycelia touching the plant tissues; controls used clean media disks. Each isolate was tested on four plants arranged in a randomized complete block design. Development of root rot lesions was monitored and evaluated $14 \mathrm{~d}$ after inoculation when some roots were completely girdled with necrotic lesions. Re-isolation from the lesions was done and cultures were compared with the original inoculum to confirm Koch's postulates. The pathogenicity tests were repeated once.

Identification and characterization of fungal pathogens and endophytic biocontrol agents. Fungal isolates, confirmed as pathogens in pathogenicity tests, were microscopically observed and grouped into morphological types. Bacterial endophytes were observed and characterized using colony morphology, Gram staining, cell morphology, and DNA sequence analysis. The DNA of fungal pathogens and bacterial endophytes was extracted using FastDNA kit (MP Biomedical, Solon, OH) following the manufacturer's instruction manual. The concentration of the DNA and relative purity was checked using a Nanodrop Lite (Thermo Fisher Scientific, Wilmington, $\mathrm{DE})$. Two universal polymerase chain reaction (PCR) primers, ITS1 (5'-TCC GTA GGT GAA CCT TGC GG-3') and ITS4 (5' -TCC TCC GCT TAT TGA TAT GC- $3^{\prime}$ ) were used to amplify the ribosomal DNA (rDNA) from fungi. Primer pairs RW01 (5'-AAC TGG AGG AAG GTG GGG AT-3') and DG74 (5'-AGG TGA TCC AAC CGC A-3') were used to amplify a 370 base pair (bp) region of the $16 \mathrm{~S}$ ribosomal RNA (rRNA) gene for bacterial isolates.

The PCR analysis of the genomic DNA was carried out in a final volume of $25 \mu \mathrm{L}$ with PCR buffer $1 \mathrm{X}$ (Promega, Madison, WI), $2.5 \mathrm{~mm} \mathrm{MgCl}_{2}, 200 \mu \mathrm{M}$ of each deoxynucleoside triphosphate (dNTP), 100 pM of primer, $100 \mathrm{ng}$ genomic DNA, and 2.5 units of Taq polymerase (Promega). Amplification was carried out using a PTC 100 Thermal Cycler (Boier Lifepro, Grand Island, NY) programmed with an initial denaturation temperature of $95{ }^{\circ} \mathrm{C}$ for $5 \mathrm{~min}$, followed by 34 cycles consisting of denaturation at $95{ }^{\circ} \mathrm{C}$ for $1 \mathrm{~min}$, annealing of the primers at $55{ }^{\circ} \mathrm{C}$ for $1 \mathrm{~min}$, and $1-\mathrm{min}$ initial extension at $72{ }^{\circ} \mathrm{C}$ followed by $10 \mathrm{~min}$ of final extension at $72{ }^{\circ} \mathrm{C}$.

Twenty microliters of the PCR amplified products were separated on a $2 \%$ agarose gel (w/v) (Phenix, Candler, NC) alongside 100-bp ladder size standard to determine the size and quality of DNA fragments. GelRed stain $(0.1 \mu \mathrm{g} / \mathrm{mL})$ was used to aid nucleic acid visualization. Electrophoresis was performed at 50 to $60 \mathrm{~V}$ for $40 \mathrm{~min}$ in $1 \mathrm{X}$ Tris borateEDTA buffer. The gels were photographed using Kodak Gel logic 200 (Carestream, Rochester, NY) under ultraviolet light. The PCR products were purified using the Exosap DNA purification kit (Invitrogen, Life Technologies, Inc., Carlsbad, CA) following the manufacturer's recommended protocols. The PCR products were sent to Eurofins genomics (Louisville, KY) for sequencing. Sequences were aligned using the online alignment tool BLAST. Identification of each endophyte was determined by comparing its DNA sequence with sequences previously deposited in GenBank (NCBI) using the closest similarity match at $\geq 99 \%$ identity.

Isolates that matched $B$. thuringiensis, Bacillus cereus, and Bacillus anthracis were examined for the presence of parasporal crystals that are associated with $B$. thuringiensis (Ejiofor and Johnson, 2002). Isolates were incubated for $72 \mathrm{~h}$ on medium containing yeast extract, $\left(\mathrm{NH}_{4}\right)_{2} \mathrm{SO}_{4}, \mathrm{~K}_{2} \mathrm{HPO}_{4} .3 \mathrm{H}_{2} \mathrm{O}$, $\mathrm{MgSO}_{4} .7 \quad \mathrm{H}_{2} \mathrm{O}, \mathrm{CaCl}_{2} .2 \mathrm{H}_{2} \mathrm{O}, \mathrm{MnSO}_{4} .4$ $\mathrm{H}_{2} \mathrm{O}$, and glucose. A differential crystal staining technique was then conducted following the protocol described by Ejiofor and Johnson (2002). The presence of crystal proteins produced during sporulation is solely characteristic of $B$. thuringiensis and not the related bacteria, $B$. cereus or B. anthracis, which are human pathogens.

Screening of endophytes as BCAs of fungal pathogens. Eight bacterial endophytes including five presented in Table 2 and three (B17A, $\mathrm{B} 17 \mathrm{~B}$, and IMC8) previously isolated from C. florida stem pieces and found to suppress Erysiphe pulchra (Mmbaga et al., 2018b; Rotich et al., 2019), were evaluated for antimicrobial activity against 11 soilborne fungal pathogens presented in Table 1 and Glomerella acutata previously isolated as a soilborne pathogen. The antimicrobial activity was assessed using a dual culture technique in which bacterial endophytes and fungal pathogens were placed at opposite sides of the petri plates containing both potato dextrose agar (PDA) and NA at $1: 1 \mathrm{v} / \mathrm{v}$ ratio to support growth of both the fungal pathogens and the bacterial endophytes. Initial inoculum consisted of mycelial plugs of fungal pathogen (5-mm radius) from 7-d-old cultures grown on PDA, and 5-mm plugs of bacterial endophytes collected from 24-h cultures grown on NA. The controls consisted of fungal pathogens alone and endophytes alone. All plates were incubated at ambient temperature of 20 to $23{ }^{\circ} \mathrm{C}$. The effects of bacterial endophytes on growth of the fungal pathogens were measured after 7-d growth. Percentage growth inhibition (PGI) was calculated using the formula: PGI $(\%)=$ $(\mathrm{GC}-\mathrm{GE}) / \mathrm{GC} \times 100$ in which $\mathrm{GC}=$ growth of fungal pathogen control plate and $\mathrm{GE}=$ growth of fungal pathogen in the presence of the endophytic bacteria. Each isolate was evaluated with four replicates, and the study was repeated once.

The data obtained were subjected to analysis of variance using SAS 9.4 software. Mean values among treatments were compared by using the least significant difference (LSD) test at $P=0.05$. Mean comparisons were conducted using Fisher's LSD at $P \leq 0.05$.

Biochemical substances from endophytes as potential mechanisms of antagonism to fungal pathogens. This study was conducted to assess the presence of antagonistic diffusible metabolites in the media at the inhibition zone between the endophyte and the fungal pathogens. To ensure that the media from the inhibition zone did not contain any bacterial cells, 5.0-mm plugs of the media were plated on NA and monitored for growth of bacteria. Subsequently, bacteria-free 5.0-mm plugs 
Table 1. Soilborne fungi isolated from snap bean roots and from their rhizosphere soil in Tennessee.

\begin{tabular}{llllrc}
\hline Sample ID & Source & \multicolumn{1}{c}{ Organism identity } & Accession no. & $\begin{array}{r}\text { Percent } \\
\text { identity }\end{array}$ & $\begin{array}{c}\text { Necrosis } \\
\text { incidence }^{z}\end{array}$ \\
\hline PA-SN1-L2 & Snap bean & Peyronellaea pinodella & KM030324.1 & 100 & 20 \\
PA-SN3-L1 & Snap bean & Fusarium oxysporum & KF494076.1 & 100 & 30 \\
PA-SN1-R1 & Snap bean & F. oxysporum & KP942940.1 & 100 & 28 \\
PA-SN4-R1 & Snap bean & F. oxysporum & KM486071.1 & 99 & 28 \\
JJ5 & Soil & F. oxysporum & FJ605247.1 & 99 & 35 \\
JJ5 & Soil & Fusarium equiseti & AB425996.1 & 99 & 20 \\
JJ8 & Soil & Fusarium subglutinans & JN646040.1 & 100 & 30 \\
JJ8 & Soil & Fusarium camptoceras & EU520082.1 & 99 & 20 \\
JJ9 & Soil & Fusarium chlamysosporum & KM076600.1 & 99 & 20 \\
JJ9 & Soil & Fusarium verticillioides & KC752592.1 & 100 & 25 \\
JJ10 & Soil & Fusarium proliferatum & KJ608094.1 & 99 & 17 \\
JJ11 & Soil & Fusarium acuminatum & KF887088 & 99 & 17 \\
JJ15 & Soil & Fusarium solani & HQ262512 & 99 & 20 \\
J116 & Soil & Macrophomina phaseolina & JX945170 & 100 & 80 \\
\hline ZIncidence
\end{tabular}

${ }^{\mathrm{z}}$ Incidence of root necrosis in pathogenicity tests on snap beans varied from $17 \%$ to $80 \%$ of roots showing root rot lesions with symptoms of brown to reddish-brown lesions.

Table 2. Molecular identification of endophytes isolated from different hosts and their identity based on closest similarity match in DNA sequence with GenBank accessions.

\begin{tabular}{lllcl}
\hline Sample ID & \multicolumn{1}{c}{ Source } & \multicolumn{1}{c}{ Organism identity } & Percentage identity & Accession no. \\
\hline PS & Papaya stem & Bacillus vallismortis & 99 & KJ642605.1 \\
Prt & Papaya root & Bacillus subtilis & 99 & AB894357.1 \\
Psl & Papaya stem & Bacillus amyloliquefaciens & 99 & KU551259 \\
E & Snap bean root & Enterobacter sp. & 100 & KJ526911.1 \\
Y & Dogwood stem & Bacillus anthracis & 99 & CP010852.1 \\
& & Bacillus thuringiensis & 99 & CP010577.1 \\
& & Bacillus cereus & 99 & CP010577.1 \\
\hline
\end{tabular}

${ }^{\mathrm{z}}$ Confirmed identity based on Ejiofor and Johnson (2002).

from the inhibition zone were evaluated for the ability to suppress growth of the fungal pathogens by using dual cultures in which a pathogen plug was placed at the center of the 85-mm petri dish and four 5-mm plugs of bacteria-free agar from the inhibition zones were placed at equidistant positions $(2.75 \mathrm{~cm})$ from the pathogen plug. The control consisted of one 5-mm pathogen plug at the center of the 85-mm petri dish and media plugs from noninoculated NA at equidistant positions from the pathogen. Treatments were replicated four times. All plates were incubated at $25 \pm 2{ }^{\circ} \mathrm{C}$, arranged in a randomized complete block design for $14 \mathrm{~d}$. Growth of fungal pathogens was measured and the pathogen growth inhibition by bacteria-free plugs was calculated as explained previously. The experiment was repeated once.

A second study was conducted to ascertain if potent biochemical substances released by the BCAs can pass through a $0.22-\mu \mathrm{m}$ filter membrane (Sigma Aldrich, St. Louis, MO) into the media and inhibit pathogen growth in the absence of the bacterial cells. Sterile membrane filters were overlaid on PDA/NA at the center of the 85$\mathrm{mm}$ petri plate and the selected endophytes were placed at the center and allowed to grow for $24 \mathrm{~h}$; the membrane bearing the bacterial culture was then removed from the petri plate and a 5-mm mycelial plug of a fungal pathogen (M. phaseolina) was placed at the center of the plate where the membrane had been laid. A control treatment consisted of clean NA media plug and the pathogen (M. phaseolina) placed at the center of the plate where the membrane had been laid on the plate. Plates were replicated four times and the percentage inhibition of colony growth of the fungal pathogen was measured and compared with the control treatment as described previously.

\section{Results}

Isolation and identification of root rot pathogens and endophytic BCAs. Only two pathogens, $P$. pinodella and $F$. oxysporum, were isolated from symptomatic plant tissue that displayed shoot wilting, seedling stunting, and brown root lesions (Table 1). Pathogenicity tests of $P$. pinodella and $F$. oxysporum on snap bean seedlings revealed root rot lesions that developed on all inoculated plants, but not in the noninoculated controls. The necrotic root lesions were brown to reddish brown in color and completely girdled the roots in $14 \mathrm{~d}$ after inoculation. The pathogenicity test of other fungi isolated from rhizosphere soil produced root lesions that were similar to those produced by $P$. pinodella and $F$. oxysporum with no distinct symptom separation of the different fungi. The re-isolation of fungi that were morphologically similar to the original inoculum confirmed Koch's postulate and indicated that the fungi were associated with the root lesions. The initial field symptoms of shoot wilting, seedling stunting, and brown root lesions can be considered nondistinct. Thus, it is possible that disease symptoms observed in the field may be a result of a disease complex from the two fungi or a disease complex that involved other fungi in the rhizosphere soil. Several fungi isolated from the rhizosphere soil, including $F$. equiseti, $F$. subglutinans, F. camptoceras, F. chlamydosporum, $F$. verticillioides, $F$. proliferatum, and
M. phaseolina, have been reported to be pathogens in other plants (Table 1).

Of the different baits used to isolate fungi from the rhizosphere soil, leaf discs of Pieris japonica resulted in the isolation of the most numerous fungal isolates, followed by pine, carrot, and apples, respectively. Based on previous results, these baits were most effective in the isolation of diverse soilborne pathogens from rhizosphere soil. Morphological characteristics of various Fusarium species isolated from the rhizosphere soil were consistent with the identified species according to Nelson et al. (1983). Results from pathogenicity tests in growth chamber experiments showed that all the previously mentioned fungi were pathogenic on snap beans and produced similar symptoms consisting of brown to reddish-brown necrotic lesions on snap bean roots of test plants, whereas the PDA agar control did not cause symptoms. This observation further suggested that these fungi may have contributed to the seedling stunting, leaf blight, shoot wilting, and brown root lesions observed in the field.

Of the bacteria isolated as endophytes, different morphological types were recognized and identified. Bacillus strains were most frequently isolated, Enterobacter sp. being the only other genus (Table 2). Isolate PS from papaya stem had the highest similarity match to B. vallismortis at $99 \%$ (GenBank number KJ642605.1), isolate Prt from papaya roots with $99 \%$ similarity match with B. subtilis (GenBank number AB894357.1), and Psl from papaya leaves having a similarity match at $99 \%$ identity to two bacteria, B. subtilis (GenBank number HQ266666.1) and B. amyloliquefaciens (GenBank number KU551259.1). Isolate $\mathrm{Y}$, endophytic in dogwood, matched three Bacillus species, $B$. anthracis, $B$. thuringiensis, and $B$. cereus, at $99 \%$ identity (Table 2). Staining in isolate $\mathrm{Y}$ revealed the presence of crystal proteins with spherical or ovoid morphology and confirmed that this isolate was $B$. thuringiensis and not $B$. cereus or $B$. anthracis, which do not form crystal proteins. Isolate $E$ was identified as Enterobacter sp. at $100 \%$ identity (GenBank number KJ526911.1).

Screening of the endophytes as BCAs for diverse fungal pathogens. Results in dual culture experiments showed that the selected endophytes caused significant colony growth inhibitions to seven species of Fusarium and three other soilborne pathogens (Figs. 1 and 2 ). Different endophytes caused significant growth inhibitions against diverse fungal pathogens and differences in pathogen/endophyte interactions were significant at $P=0.001$. Inhibition zones for $M$. phaseolina was highest, and the degree of growth inhibition by different endophytes is presented in Fig. 2 . The effect of the selected endophytes in suppressing pathogen growth varied between pathogens (Figs. 1 and 2). All endophytes were effective in inhibiting growth of Fusarium species, especially $F$. verticillioides and $F$. oxysporum (Fig. 1). Isolates $\mathrm{Y}$ and IMC8, both $B$. thuringiensis, were the most effective in inhibiting Fusarium species, 


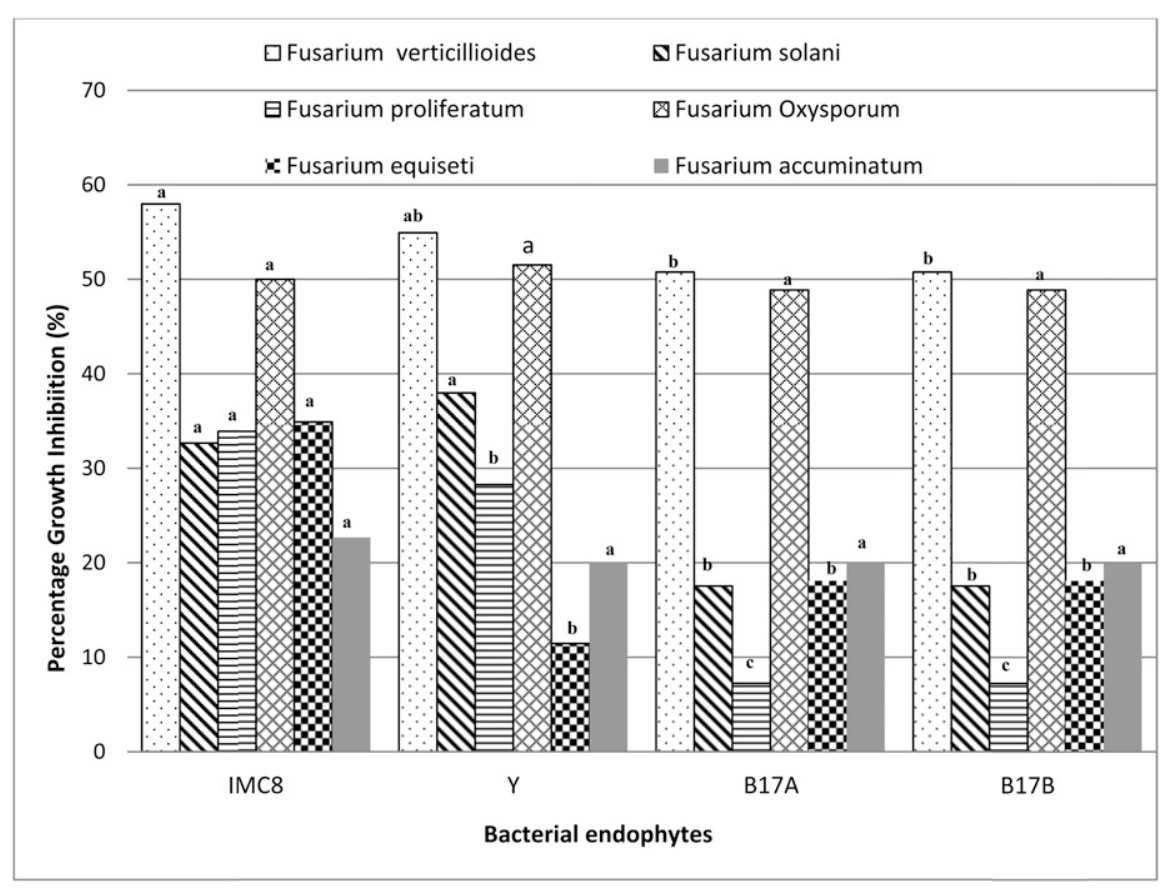

Fig. 1. The performance of bacterial endophytes in suppressing mycelial growth of diverse Fusarium species in dual cultures exhibiting their potential as biological control agents. Bacterial endophytes IMC8 (Bacillus thuringiensis); Y (B. thuringiensis); B17A (Stenotrophomonas sp.); and B17B (Serratia sp.). Different letters in each fungal pathogen (column patterns) indicate statistical differences at $P=0.05$ according to SAS Prolog analysis.

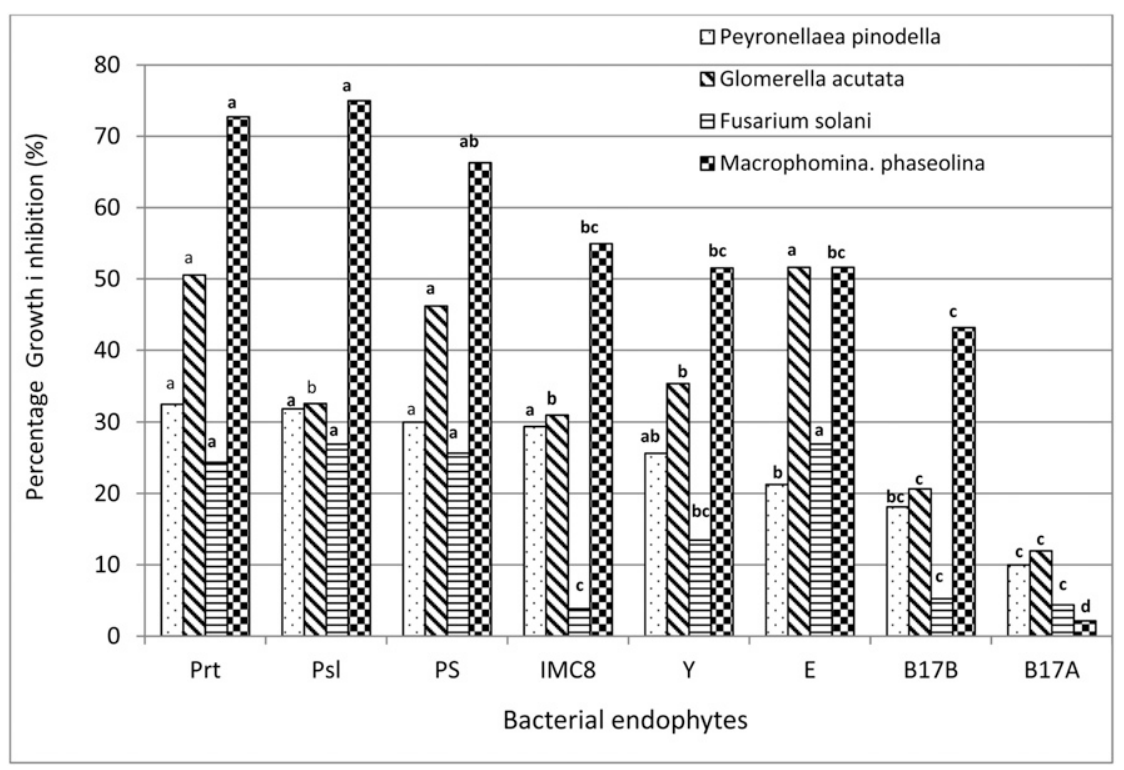

Fig. 2. The performance of bacterial endophytes in suppressing mycelial growth of diverse fungal pathogens in dual cultures indicating their potential as biological control agents. Bacterial endophytes PS (Bacillus vallismortis); Prt (Bacillus subtilis); Psl (Bacillus amyloliquefaciens); Y (Bacillus thuringiensis) and E (Enterobacter), B17A (Stenotrophomonas sp.), B17B (Serratia sp.), IMC8 (B. thuringiensis). Different letters in each fungal pathogen (column patterns) indicate statistical differences at $P=0.05$ according to SAS Prolog analysis.

whereas isolates Prt, Ps, and Psl were most effective against $M$. phaseolina and B17A (Stenotrophomonas sp.), and B17B (Serratia sp.), being least effective (Fig. 2).

Assessment of diffusible metabolites as potential mediators of BCA antagonism. Using agar plugs from the growth inhibition zone, free of bacterial cells, caused growth inhibition of pathogens (Fig. 3A-C). The use hibition was also observed in the absence of bacterial cells.

\section{Discussion}

Most fungi isolated from the snap bean fields not treated with chemical fungicides were Fusarium species. Most of the fungi were isolated from the rhizosphere soil and not from plant roots. Similar observations were reported by Avanzato and Rothrock (2010). It is possible that the Fusarium species may be weak pathogens of snap beans in natural environments. The fungi isolated from the rhizosphere soil (but not from snap bean roots) produced necrotic lesions on snap beans in growth chamber conditions. It is possible that the growth chamber environment used for pathogenicity tests was more favorable for disease development than the field environment where the fungi were isolated. However, the presence of these pathogenic fungi in snap bean rhizosphere soil and the proven pathogenicity of these fungi on inoculated beans have implications regarding their potential threat when conditions favor plant infection or when another favorable host is grown. Most of the Fusarium species isolated in snap bean rhizosphere soil are well known and widespread pathogens of corn, causing stalk and ear rot worldwide (Nelson et al., 1981, 1983). The presence of these fungi in snap bean rhizosphere soil in organic production fields may be significant not only as potential root rot pathogens, but also as toxin-producing fungi and potential contaminants of produce from these fields. Example, $F$. subglutinans has been reported to produce disease symptoms such as shoot and leaf blight, shoot wilting, seedling stunting, heavy colonization of coleoptiles, and node damage on corn plants, but had no effect on seedling emergence and survival (Aboul-Nasr and ObiedAllah, 2013). Although F. subglutinans was only isolated from snap bean rhizosphere soil and not from plant tissues, the symptoms observed in field plants in our study could have been partly caused by $F$. subglutinans. Other reports show that $F$. subglutinans is a distinct species in the Gibberella fujikuroi species complex and a pathogen of Pinus patula seedlings. Similarly, $F$. verticillioides (syn. F. moniliforme) were isolated from soil, but not from plant tissue. Other species isolated from bean rhizosphere soil, such as $F$. camptoceras, $F$. acumintum, and $F$. equiseti, $F$. chlamydosporum $F$. solani, $F$ proliferatum, Fusarium graminearum, and $F$. oxysporum, have widespread distribution, survive a long time in crop debris and soil, and may have been pathogens in a previous crop. However, $F$. oxysporum was also isolated from symptomatic snap beans. Because most of these Fusarium species are toxin-producing and have the ability to produce and accumulate mycotoxins in infected tissues, they potentially endanger humans and animals, subsequently causing food rejections (AboulNasr and Obied-Allah, 2013; Asran and Buchenauer, 2002; Nelson et al., 1993). The ability of the selected endophytic bacteria to suppress growth of toxin-producing Fusarium 

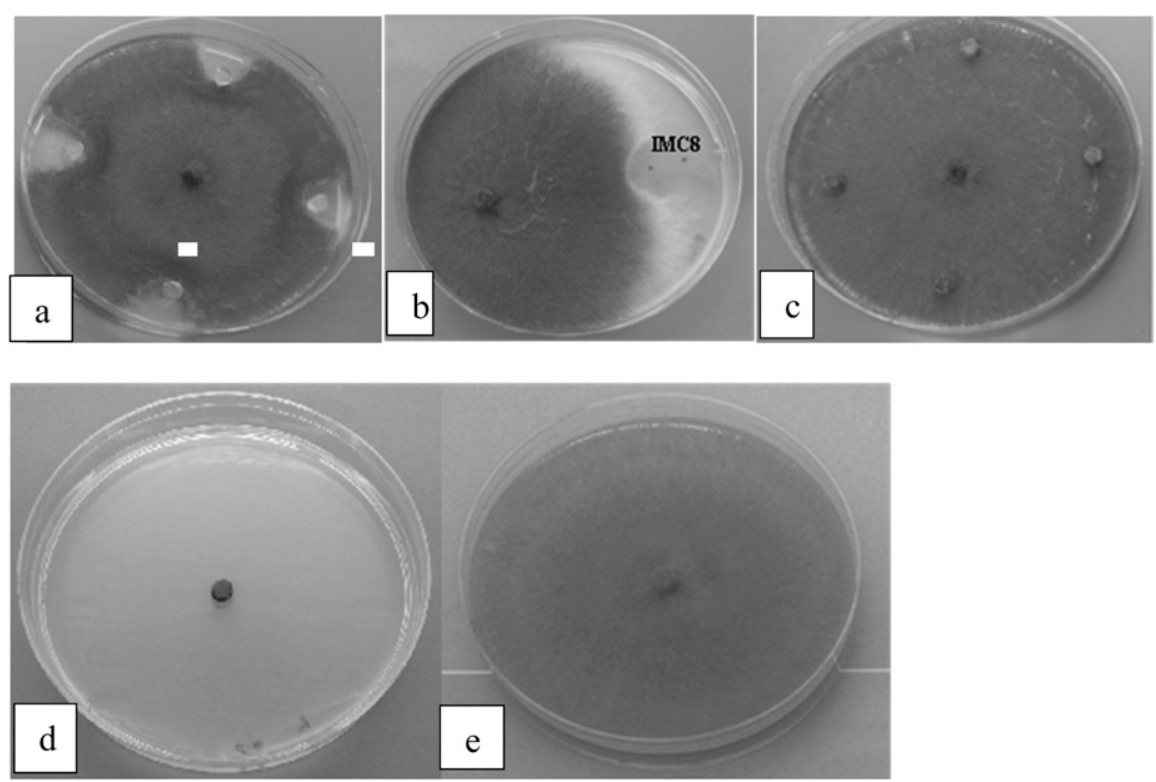

Fig. 3. Effect of diffusible metabolites released by different Bacillus species into growth media inhibiting M. phaseolina mycelial growth in culture in the absence of bacterial cells: (A) metabolites from the Prt (Bacillus subtilis) inhibition zone, (B) metabolites from the IMC8 (Bacillus thuringiensis) inhibition zone, (C) control treatment from plain nutrient agar (NA), (D) $100 \%$ growth inhibition of Macrophomina phaseolina from biochemical substances from isolate $\mathrm{Y}$ (B. thuringiensis) grown on a $0.22-\mu \mathrm{m}$ filter membrane overlaid on potato dextrose agar (PDA)/NA media for $24 \mathrm{~h}$ and then removed compared with (E) mycelial growth of M. phaseolina on plain PDA/NA.

Table 3. Growth inhibition of Macrophomina phaseolina colonies in dual culture by bacteria-free media plugs taken from inhibition zones: 1) horizontal diffusion of metabolites released by endophytes and 2) vertical diffusion through filter membranes overlaid on the media.

Growth inhibition of M. phaseolina colonies in the presence of diffusible metabolites

\begin{tabular}{|c|c|c|c|c|}
\hline $\begin{array}{l}\text { Bacterial } \\
\text { endophytes }\end{array}$ & $\begin{array}{l}\text { \% growth } \\
\text { inhibition }^{y}\end{array}$ & $\begin{array}{l}\text { Bacteria-free plugs } \\
\text { from inhibition zone } \text { e }^{\mathrm{x}, \mathrm{w}}\end{array}$ & $\begin{array}{l}\text { Bacteria-free plugs } \\
\text { underneath filter membrane }{ }^{\mathrm{x}, \mathrm{w}}\end{array}$ & $\begin{array}{c}\text { Bacterial } \\
\text { cell plugs }\end{array}$ \\
\hline IMC8 & $54.93 \mathrm{bc}$ & + & ++ & ++ \\
\hline Y & $51.52 \mathrm{~cd}$ & + & ++ & ++ \\
\hline $\mathrm{E}$ & $51.63 \mathrm{~cd}$ & + & ++ & ++ \\
\hline Prt & $72.73 \mathrm{a}$ & ++ & ++ & +++ \\
\hline PS & $66.29 \mathrm{ab}$ & + & + & +++ \\
\hline Psl & $75.00 \mathrm{a}$ & + & + & +++ \\
\hline Control & 0 & - & - & NA \\
\hline $\operatorname{LSD}_{(0.05)}$ & 11.91 & & & \\
\hline
\end{tabular}

${ }^{\mathrm{z}}$ Endophytes IMC 8 and $\mathrm{Y}=$ Bacillus thuringiensis; PS (Bacillus vallismortis); Prt (Bacillus subtilis); Ps (Bacillus amyloliquefaciens); E (Enterobacter), and Control (plain media). LSD = least significant difference. No inhibition (-), slight inhibition of M. phaseolina $(+)$, good inhibition $(++)$, best inhibition (+++). NA = not applicable, no bacterial cells.

${ }^{\mathrm{y}}$ Bacterial cells are present.

${ }^{\mathrm{x}}$ Horizontal diffusion of metabolites from bacterial endophytes.

${ }^{\mathrm{w}}$ No bacterial cells present. Numbers followed by different letters are significantly different at $P=0.05$.

species has significant implications beyond the field production of snap beans, and may be a resource in the management of toxinproducing Fusarium species. Results from this study identified isolates of Bacillus species that have previously been documented to have an inhibitory effect on fungal pathogens (Hallmann et al., 1997; Heydari and Pessarakli, 2010). The isolation and identification of these new isolates presents potential new sources of BCAs for diverse fungal pathogens, including toxinproducing Fusarium species. Significant differences in growth inhibition by different endophytes against diverse fungal pathogens $(P=0.001)$ suggest that mixtures of endophytes could be used in plant protection for optimal control.

The DNA results of isolate Psl revealed its identity as either a B. amyloliquefaciens or B. subtilis strain, with both having $99 \%$ identity, and so it was difficult to distinguish them by molecular techniques. This difficulty was also reported by Hutsebaut et al. (2006), in which B. subtilis and B. amyloliquefaciens showed more than $99 \%$ similarity. They reported insufficient dissimilarity in the species of $B$. subtilis when pairwise alignment of 16S rRNA gene sequences analysis was done (Hutsebaut et al., 2006). Although the use of $16 \mathrm{~S}$ rDNA sequence analysis is very common in assigning strains into different taxa, it is difficult to detect any variation when distinguishing closely related organisms (De Vos, 2002; Fox et al., 1992). The endophytes matched to members of the $B$. subtilis group pose particular identification problems: the $B$. subtilis group consists of $B$. subtilis subsp. subtilis, B. subtilis subsp. spizizenii, Bacillus mojavensis, B. vallismortis, Bacillus clausii, Bacillus atrophaeus, B. amyloliquefaciens, Bacillus licheniformis, Bacillus sonorensis, Bacillus firmus, Bacillus lentus, and Bacillus sporothermodurans (Standards Unit, Microbiology Services and PHE, 2015). Several studies have been conducted attempting to distinguish $\mathrm{Ba}$ cillus species based on different phenotypic characteristics, such as fatty acid composition, pigmentation (Roberts et al., 1996), and analytical profile index (Logan and Berkeley, 1984). Thus, confirmatory identities of these endophytes require more studies using whole-genome DNA sequence analysis. The presence of crystal proteins (Ejiofor and Johnson, 2002) indicated that our isolates $Y$ and a previously isolated endophyte of flowering dogwood IMC8 are strains of B. thuringiensis. The effect of $B$. thuringiensis isolates $\mathrm{Y}$ and IMC8 in suppressing growth of fungal pathogens is interesting in that $B$. thuringiensis is a well-known insect pathogen widely used in commercial biological control. Our recent studies showed that IMC8 has suppressed powdery mildew disease severity in C. florida (Rotich et al., 2019). Bacillus isolates Psl, PS, and Prt suppressed phytophthora root rot in bell pepper (Irabor and Mmbaga, 2017) and soybean root rot caused by $F$. oxysporum and Fusarium graminearum (Zhang et al., 2009); their ability to suppress diverse fungal pathogens increases their prominence as potential BCAs.

The bacterium Enterobacter sp. was isolated as an endophyte of snap bean roots from a grower's farm in Tennessee; however, Enterobacter spp. is present almost everywhere in nature, particularly in the rhizosphere and spermosphere of most plant species (Haahtela et al., 1981; Ladha et al., 1983). Some Enterobacter spp. have been reported to promote plant growth (Deepa et al., 2010; Ramesh et al., 2014), associated with nitrogen fixing in rice (Ladha et al., 1983) and control some plant diseases (Howell et al., 1988; Mmbaga and Joshua, unpublished). Isolates B17A (Stenotrophomonas sp.) and B17B (Serratia sp.) have previously demonstrated disease control against powdery mildew and growth-promoting abilities in C. florida (Mmbaga et al., 2018b) and soybeans (Wahyudi et al., 2011).

Numerous bacterial strains have been shown to protect plants against pathogens and promote growth in different ways, such as inhibition, competition, or increasing plant resistance (Idris et al., 2007; Richardson et al., 2009). Several species, such as $B$. subtilis, $B$. licheniformis, Bacillus pumilus, B. amyloliquefaciens, B. cereus, and $B$. thuringiensis, have been reported to suppress growth of various fungal pathogens, such as Rhizoctonia, Fusarium, Sclerotinia, Sclerotium, Gaeumannomyces, Nectria, Pythium, Phytophthora, and Verticillium species (Basurto-Cadena 
et al., 2012; Haleem Khan et al., 2011; Zhang et al., 2009).

The screening of bacterial endophytes in our in vitro studies showed clear inhibition zones. The use of dual cultures is a rapid and convenient method to evaluate endophytes as potential BCAs against plant pathogens before testing them on whole plants. Our studies are supported by the approach of Islam et al. (2005), who used the existence of inhibition zones as criteria in screening and selecting potential BCAs. Our studies showed that the inhibition zones harbored unidentified compounds, diffused into the media. Such compounds inhibited fungal growth in the absence of bacterial cells. Although the compounds have not yet been identified, results showed clearly that bioactive metabolites were effective in suppressing fungal pathogens. This agrees with reports by Clay and Schardl (2002), Webber (1981), Raaijmakers et al. (2002), and Heydari and Pessarakli (2010) that bacterial antagonists inhibit the growth of fungal pathogens by excreting antifungal metabolites, such as antibiotics, toxins, and bio-surfactants, including volatiles. The diffusion of the compounds to the media where bacteria were grown on filter membranes displayed greater inhibition, perhaps because of higher concentrations where the bacteria were grown on the micro filter membranes (Fig. 3).

Differences in growth inhibition between the isolates also suggested that different bacterial endophytes may produce different compounds and/or amounts of antifungal substances. However, these differences in the antagonistic effect against different pathogens suggest a possibility for using mixed populations of endophytes to maximize control of fungal pathogen complexes. Isolates $\mathrm{B} 17 \mathrm{~A}$ and $\mathrm{B} 17 \mathrm{~B}$, previously isolated as epiphytes of flowering dogwood, suppressed powdery mildew disease severity and promoted plant growth in dogwood plants even when applied on the roots (Mmbaga et al., 2016). The isolates also colonized dogwood endophytically and were antagonistic to Macrophomina root rot in this host (Mmbaga et al., 2018b). Notwithstanding, this study showed that B17A and B17B were most effective against $F$. oxysporum and $F$. verticillioides and less effective against other soilborne fungi tested, including M. phaseolina (Fig. 3). These results suggest that there is some host specificity as well as pathogen/endophyte specificity in bioactivity of these endophytes. Endophytic organisms used in this study are likely to be naturally abundant and less vulnerable to external environmental fluctuations, and therefore more likely to confer effective disease control in field environments. Such BCAs can be integrated with other cultural strategies, including sanitation and crop rotation in a biological-based integrated disease management system for maximized disease control in organic farming.

Our results showed that the extent of growth inhibition resulting from plugs taken from bacteria-free inhibition zones was greatly reduced compared with plugs con- taining the bacterial cells (Table 3 ). The pathogen inhibition evident in the absence of the bacterial cells indicates that the selected endophytes may not have to be physically present for pathogen inhibition to occur, but the inhibition increased when bacterial cells were present. These observations suggest that more than one mechanism of action may be involved. Manipulating such organisms to be "super producers" of antagonistic metabolites may improve their efficacy. Observations from this study create considerable potential for the development of disease management products that may be compatible with organic production; however, more studies are needed to identify and characterize the secondary metabolites and test the organisms in vivo.

\section{Literature Cited}

Aboul-Nasr, M.B. and M.R.A. Obied-Allah. 2013. Biological and chemical detection of fumonisins produced on agar medium by Fusarium verticillioides isolates collected from corn in Sohag, Egypt. Microbiology 159:1720-1724.

Asran, M.R. and H. Buchenauer. 2002. Virulence of Fusarium moniliforme isolates on maize plants in relation to fumonisin and ergosterol levels. Plant Dis. Protect. 109:491-505.

Avanzato, M.V. and C.S. Rothrock. 2010. Use of selective media and baiting to detect and quantify the soilborne plant pathogen Thielaviopsis basicola on pansy. The Plant Health Instructor, doi: 10.1094/PHI-I-2010-0610-01.

Barnard, J. 2010. EPA will limit pesticides near salmon streams. MSNBC. Associated Press, Seattle, WA.

Basurto-Cadena, M.G.L., M. Vazquez-Arista, J. Garcia-Jimenez, R. Salcedo-Hernandez, D.K. Bideshi, and J.E. Barboza-Corona. 2012. Isolation of new Mexican strain of Bacillus subtilis with antifungal and antibacterial activities. Scientific World J. 2012:384978.

Bost, S. 2006. Root rot and seedling disease of beans and peas. UT extension. $<$ https://extension. tennessee.edu/publications/Documents/SP277O.pdf $>$.

Bost, S., F. Hale, A. Straw, and C. Pless. 2013. Crop profile for snap beans in Tennessee. 15 Jan. 2018. <http://www.ipmcenters.org/CropProfiles/docs/TNSnapbean2003.pdf>.

Burns, C.J., L.J. McIntosh, P.J. Mink, A.M. Jurek, and A.A. Li. 2013. Pesticide exposure and neurodevelopmental outcomes: Review of the epidemiologic and animal studies. J. Toxicol. Environ. Health B Crit. Rev. 16:127-283.

Clay, K. and C. Schardl. 2002. Evolution origins and ecological consequences of endophyte symbiosis with grasses. Amer. Nat. 160:99-127.

Collinge, D.B., H.J. Jorgensen, O.S. Lund, and M.F. Lyngkjaer. 2010. Engineering pathogen resistance in crop plants: Current trends and future prospects. Annu. Rev. Phytopathol. 48:269-291.

Deepa, C.K., S.G. Dastager, and A. Pande. 2010 Isolation and characterization of plant growth promoting bacteria from non-rhizospheric soil and their effect on cowpea Vigna unguiculata L. Walp. Seedling growth. World J. Microbiol. Biotechnol. 26:1233-1240.

De Vos, P. 2002. Nucleic acid analysis and SDSpage of whole-cell proteins in Bacillus taxonomy, p. 141-159. In: R. Berkeley, M. Heyndrickx, N. Logan, and P. De Vos (eds.). Applications and systematics of Bacillus and relatives. 1st ed. Blackwell Publishing, Hoboken, NJ.
Ejiofor, A.O. and T. Johnson. 2002. Physiological and molecular detection of crystalliferous $\mathrm{Ba}$ cillus thuringiensis strains from habitats in the South Central United States. J. Ind. Microbiol. Biotechnol. 28:284-290.

Fernando, W.G.D., J.D. Miller, W.L. Seaman, K. Seifert, and T.C. Paulitz. 2000. Daily and seasonal dynamics of airborne spores of Fusarium graminearum and other Fusarium species sampled over wheat plots. Can. J. Bot. 78:497-505.

Fox, G.E., J.D. Wisotzkey, and P. Jurtshuk, Jr. 1992. How close is close: $16 \mathrm{~S}$ rRNA sequence identity may not be sufficient to guarantee species identity. Int. J. Syst. Bacteriol. 42:166-170.

Francl, L., G. Shaner, G. Bergstrom, J. Gilbert, W. Pedersen, R. Dill-Macky, L. Sweets, B. Corwin, Y. Jin, D. Gallenberg, and J. Wiersma. 1999. Daily inoculum levels of Gibberella zeae on wheat spikes. Plant Dis. 83:662-666.

Haahtela, K., T. Wartiovaara, V. Sundman, and J. Skujins. 1981. N2-fixation (acetylene reduction) by Enterobacteriaceae and Azospirillum strains in cold-climate spodosols. Appl. Environ. Microbiol. 41:203-206.

Haleem Khan, A., R. Naseem, and B. Prathibha. 2011. Screening and potency evaluation of antifungal from soil isolates of Bacillus subtilis on selected fungi. Advanced Biotech. 10:35-37.

Hallmann, J., A. Quadt-Hallmann, W.F. Mahaffee, and J.W. Kloepper. 1997. Bacterial endophytes in agricultural crops. Can. J. Microbiol. 43:895-914.

Heydari, A. and M. Pessarakli. 2010. A review on biological control of fungal plant pathogens using microbial antagonists. J. Biol. Sci. 10:273-290.

Howell, C.R., R.C. Beier, and R.D. Stipanovic. 1988. Production of ammonia by Enterobacter cloacae and its possible role in the biological control of Pythium pre-emergence damping-off by the bacterium. Phytopathology 78:1075-1078.

Hutsebaut, D., J. Vandroemme, J. Heyrman, P. Dawyndt, P. Vandenabeele, L. Moens, and P. de Vos. 2006. Raman micro spectroscopy as an identification tool within the phylogenetically homogeneous 'Bacillus subtilis'-group. Syst. Appl. Microbiol. 29:650-660.

Idris, E.E., D.J. Iglesias, M. Talon, and R. Borriss. 2007. Tryptophan-dependent production of indole-3-acetic acid (IAA) affects level of plant growth promotion by Bacillus amyloliquefaciens. FZB42. Mol. Plant Microbe Interact. 20:619-626.

Irabor, A. and M.T. Mmbaga. 2017. Evaluation of selected bacterial endophytes for biocontrol potential against phytophthora blight of bell pepper (Capsicum annuum L.). J. Plant Pathol. Microbiol. 8:10.

Islam, M.T., Y. Hashidoko, A. Deora, T. Ito, and S. Tahara. 2005. Suppression of damping-off disease in host plants by the rhizoplane bacterium Lysobacter sp. strain SB-K88 is linked to plant colonization and antibiosis against soilborne Peronosporomycetes. Appl. Environ. Microbiol. 71:3786-3796.

Kelley, M.A., J.D. Flocks, J. Economos, and L.A. McCauley. 2013. Female farmworkers' health during pregnancy: Health care providers' perspectives. Workplace Health Saf. 61:308-313.

Ladha, J.K., W.L. Barraquio, and I. Watanabe 1983. Isolation and identification of nitrogenfixing Enterobacter cloacae and Klebsiella planticola associated with rice plants. Can. J. Microbiol. 29:1301-1308.

Logan, N.A. and R.C.W. Berkeley. 1984. Identification of Bacillus strains using the API system. J. Gen. Microbiol. 130:1871-1882. 
Mmbaga, M.T., S. Gurung, and A. Maheshwari. 2018a. Screening of plant endophytes as biological control agents against root rot pathogens of pepper (Capsicum annum L.). J. Plant Pathol. Microbiol. 9:3.

Mmbaga, M.T., L.M. Mackasmiel, and F.A. Mrema. 2018b. Evaluation of biological control agents for macrophomina root rot and powdery mildew in flowering dogwood (Cornus florida L.). HortScience 53:1-6.

Mmbaga, M.T. and R.J. Sauvé. 2009. Epiphytic microbial communities on foliage of fungicide treated and non-treated flowering dogwoods. Biol. Control 46:97-104.

Mmbaga, M.T., F.A. Mrema, L. Mackasmiel, and E. Rotich. 2016. Effect of bacteria isolates in powdery mildew control in flowering dogwoods (Cornus florida L.). Crop Prot. 89:5157.

Mmbaga, M.T., R.J. Sauve, and F.A. Mrema. 2008. Identification of microorganisms for biological control of powdery mildew in Cornus florida. Biol. Control 44:67-72.

Nelson, D.M., J.J. Goering, and D.W. Boisseau. 1981. Consumption and regeneration of silicic acid in three coastal upwelling systems in coastal upwelling. 1:242-256.

Nelson, P.E., A.E. Desjardins, and R.D. Plattner. 1993. Fumonisins and mycotoxins produced by Fusarium species: Biology, chemistry, and significance. Annu. Rev. Phytopathol. 31:233252.

Nelson, P.E., T.A. Toussoun, and W.F.O. Marasas. 1983. Fusarium species - an illustrated manual for fusarium research. The Pennsylvania State University Press, University Park, PA.
Norgaard, K.B. and N. Cedergreen. 2010. Pesticide cocktails can interact synergistically on aquatic crustaceans. Environ. Sci. Pollut. Res. Int. 17(4):957-967.

Pal, K.K. and B.M. Gardener. 2011. Biological control of plant pathogens. The Plant Health Instructor, doi: 10.1094/PHI-A-2006-1117-02.

Pertot, I., C. Alabouvette, E.H. Esteve, and S. Franca. 2015. Focus group SOIL-BORNE DISEASES mini-paper - the use of microbial biocontrol agents against soil-borne diseases. Agr. Innov. 117:11.

Raaijmakers, J.M., M. Vlami, and J.T. De Souza. 2002. Antibiotic production by bacterial biocontrol agents. J. Genet. Mol. Microbiol. 81:537-547.

Ramesh, A., S.K. Sharma, M.P. Sharma, N. Yadav, and O.P. Joshi. 2014. Plant growth-promoting traits in Enterobacter cloacae subsp. dissolvens MDSR9 isolated from soybean rhizosphere and its impact on growth and nutrition of soybean and wheat upon inoculation. Agr. Res. 31:5366.

Richardson, A., J.M. Barea, A. McNeill, and C. Prigent-Combaret. 2009. Acquisition of phosphorus and nitrogen in the rhizosphere and plant growth promotion by microorganisms. Plant Soil 321:305-339.

Roberts, M.S., L.K. Nakamura, and F.M. Cohan. 1996. Bacillus vallismortis sp. nov, a close relative of Bacillus subtilis, isolated from soil in Death Valley, California. Int. J. Syst. Bacteriol. 46:470-475.

Rotich, E., M.T. Mmbaga, and J.O. Joshua. 2019. Biological control of powdery mildew on Cornus florida using endophytic Bacillus thuringiensis isolate. Can. J. Plant Pathol. (in press).

Schisler, D.A., N.I. Khan, M.J. Boehm, and P.J. Slininger. 2002. Greenhouse and field evaluation of biological control of Fusarium head blight on durum wheat. Plant Dis. 86:13501356.

Standards Unit, Microbiology Services and PHE. 2015. UK standards for microbiology investigations: Identification of Bacillus species. Bacteriology-Identification | ID 9 | Issue no: 3 | Issue date: 24.02 .15 | Page: 1 of 27.

Tamez-Guerra, P., M.R. McGuire, R.W. Behle, B.S. Shasha, and L.J. Galán Wong. 2000. Assessment of microencapsulated formulations for improved residual activity of Bacillus thuringiensis. J. Econ. Entomol. 93:219-225.

USDA/NASS. 2015. State Agriculture overview. 14 Apr. 2016. <http://www.nass.usda.gov/ Quick_Stats/Ag_Overview/stateOverview.php? state $=\bar{T}$ TENNESSEE $>$.

Vorholt, J.A. 2012. Microbial life in the phyllosphere. Nat. Rev. Microbiol. 10:828-840.

Wahyudi, A.T., R. I. Astuti, M. A. Widyawati, and A. A. Nawangsih. 2011. Characterization of Bacillus sp. strains isolated from rhizosphere of soybean plants for their use as potential plant growth for promoting Rhizobacteria. J. Microbiol. Antimicrobials. 3(2):34-40.

Webber, J. 1981. A natural control of Dutch Elm Disease. Nature 292:449-451.

Zhang, J.X., A.G. Xue, and J.T. Tambong. 2009 Evaluation of seed and soil treatments with novel Bacillus subtilis strains for control of soybean root rot caused by Fusarium oxysporum and F. graminearum. Plant Dis. 93:13171323. 